\title{
EFL Learners' Learning Styles and Self-regulated Learning: Do Gender and Proficiency Level Matter?
}

\author{
Jahanbakhsh Nikoopour* \\ TEFL Department, Islamic Azad University, Northern Tehran Branch, Iran \\ Mohammad Shaker Khoshroudi \\ TEFL Department, Islamic Azad University, Northern Tehran Branch, Iran
}

\begin{abstract}
The present study attempted to investigate the interdependence of self-regulated learning and language learning styles among three levels of language learners. Their gender and language proficiency level were also taken into consideration to find out the interaction between these variables. To carry out the study, the subject was selected based on the multi-stage sampling procedure. From five universities, 200 EFL learners studying TEFL, Literature, and Translation were randomly selected. Based on their scores on the TOEFL test, the participants were divided into beginner, intermediate, and advanced levels. From each level, 30 subjects were randomly selected. The research instruments were used to collect the required data for the study. After analyzing the data, the results showed a significant relationship between the EFL learners' learning styles and their self-regulation. It was disclosed that the higher the learners' scores on language learning styles were, the more self-regulated they were. When gender was taken into account as a moderator variable, no significant correlation between language learners' learning styles and their gender was detected. It was found that both male and female learners were self-regulated in the same way. In addition, EFL learners' proficiency level significantly made a difference in their self-regulation; however, it did not affect their learning styles.
\end{abstract}

Index Terms —-learning styles, self-regulated learning, gender, proficiency level

\section{INTRODUCTION}

The process by which one attempts to acquire new knowledge is known as learning and each individual approaches the learning context differently. According to Keefe (1988), the way individuals perceive, interact, and respond to the learning environment cognitively, affectively, and psychologically which is relatively stable is called their learning style. As Pritchard (2009) stated, learning styles are not fixed; however, one learning style is preferred over others. In addition, identifying this preferred learning style could be of benefit to both learners as they choose the best learning strategies, and to teachers as they modify their teaching strategies so that they could provide better opportunities for students to learn.

In recent years, there has been a great change in the field of second/foreign language learning and teaching which was directed towards learners' individual differences such as learning styles. This change is more of a student-centered approach in which more attention is paid to individuals' roles and responsibilities in the class that, in turn, leads to learners' independency and autonomy. Self-regulated learning started as a research on self-control for learners to selfmonitor, self-instruct, self-evaluate, self-correct, and self-reinforce (Mace, Belfoire, \& Hutchinson, 2001). Unlike behavioral theories which do not take into account the learners' internal states, cognitive theories of learning started their ascendance in the 1960s and dominated as the focus of human learning. However, some researchers came to know that factors such as cognitive skills and abilities, motivation, and self-regulation account for students' teaching (Zimmerman, 2001).

According to Oxford (2003), autonomy and self-regulation are self-ruled, and learners who are autonomous and selfregulated can regulate their own thoughts, learning, and actions. Terms such as 'self-directness', 'self-control' and 'autonomy' paved the way for the emergence of the term 'self-regulation' (Bandura, 1991), and according to Najeeb (2013), learners are at the stage who are able to direct their own learning.

Different models of self-regulated learning share certain assumptions i.e. learners should be active participants and they should self-regulate and monitor their own learning process. Also, learning process should help learners to achieve their set goals and apply any required change to the process. (Curry, 1983; Pintrich, 2004). With the development of learners cognitively, their self-regulation increases and depends a lot on the use of private speech. Kopp (1989) stated that when self-regulation increases, there would be a transition in learners from responding to others' commands to plan

\footnotetext{
*Corresponding author: j_nikoopour@iau-tnb.ac.ir
} 
and monitor their own activities. This would happen when learners interact with adults through ZPD. Learners' learning style is mostly ignored and most importantly the mismatch existing between teachers' teaching style and their learning style could influence their performance negatively.

\section{LANGUAGE LEARNING STYLES}

To learn a new subject or tackle a new challenge, pupils use some general approaches which according to Oxford, Ehrman, and Lavine (1991) are addressed as language learning styles. However, Reid (1985) relates learning styles to learners' predispositions to perceive and process learning experiences.

The way a learner likes to learn is called 'learning style preferences', and according to Ehrman (1996), they are put into action by specific learning strategies. Learning styles have six aspects: the cognitive, executive, affective, social, physiological, and behavioral aspect (Oxford \& Anderson, 1995). According to Brown (2007), there exists a close link between learning strategies and learning styles. Bailey, Onwuegbuzie, and Daely (2000) distinguished the difference between learning styles and learning strategies in that the former are automatic/ unintentional individual features, whereas the latter are what learners choose to facilitate their learning.

Learning styles play important roles for the learners since they can integrate them to their learning process and accordingly their learning process would be faster and they will be more successful. Also, learners would resolve their problems more effectively when they identify their styles. When learners gain control over their learning process, they will feel more independent and responsible in learning, as a result, their self-confidence will increase and teachers' control over learners will lessen and teachers act as facilitators (Gilakjani \& Ahmadi, 2011). Merits of identifying the learning styles for teachers are to help them to design lessons to meet their students' styles. Otherwise, the created mismatch could frustrate new or poor learners. However, this mismatch could be to the advantage of the learners as to help them experience new methods of learning.

Oxford (2003) discussed four dimensions of learning style that are among the most strongly associated with L2 learning: sensory preference (visual, auditory, kinesthetic, and tactile), personality types (extraverted vs. introverted; intuitive-random vs. sensing-sequential; thinking vs. feeling; and closure-oriented/judging vs. open/perceiving, desired degree of generality (global or holistic, analytic), and biological differences (biorhythms, sustenance, location). Najarkolai, Beigzadeh, Motlagh, and Sabzevari (2015) investigated 400 postgraduate students of Kerman University of Medical Sciences, and found that the most dominant learning style of postgraduate students is the convergent style.

Moreover, Khojasteh and Pishkar (2015) studied the relationship between Iranian EFL Learners' Sensory Learning Style and Their Autonomy Level. They found that students with visual learning style in Islamic Azad University, had the highest language autonomy and the students with auditory- kinesthetic (AK) style had the lowest language autonomy. However, in State University of Hormozgan, AK (Auditory-Kinesthetic) skill is more frequently used style and visual style is the one used less frequently by the students of both universities. Additionally, as per the finding of Shah, Ahmed, Shenoy, and Srikant (2013), students in their set up prefer multimodal and more of Kinesthetic of learning.

Naserieh and AnaniSarab (2013) explored perceptual styles among Iranian graduate students by using PLSQ. The findings revealed that the participants favored kinesthetic and tactile modalities and a group learning style. Peacock (2001) did a study as to test Reid's (1987) hypothesis that mismatch between teaching and learning styles would lead to learning failure as well as frustration. A university in Hong Kong was the source of data collection and it was detected that teacher preferred auditory, kinesthetic, and group styles and did not like individual and tactile styles, whereas the students preferred auditory and kinesthetic styles and disliked group and individual styles. Therefore, Peacock (2001) suggested a balanced style for teachers to adapt to various learning styles.

According to Gregersen and MacIntyre (2014, cited in Dornyei \& Ryan, 2015), there are five principles for the practical classroom application of styles. Effective teachers know their teaching styles and self-aware learners are aware of their preferred approaches to language learning for themselves as well as for their teachers. Also, with the help of a "mixed and many" approach, teachers and learners can explore ways to balance their styles. Besides, teachers and learners compromise to occasionally stretch as well as match so as to resolve learning style conflicts, and reflective learners regard how their beliefs, strategies, and abilities relate to their individual learning styles.

Furthermore, Derakhshan and Shakki (2018) found that highly proficient EFL learners were more oriented towards kinesthetic and tactile learning styles than auditory, visual, group, and individual learning styles. On the other hand, visual and group learning styles were more favored by learners with lower level of proficiency.

\section{SELF-REGULATION LEARNING}

During the last decade, learning strategies have been studied to a great extent (Banisaeid, 2013; Banisaeid \& Huang, 2014; Chamot, 2004; Chen, 2009; El-dib, 2004; Griffiths, 2003, 2007; Griffiths \& Oxford, 2014; Magogwe \& Rhonda, 2007; Nikoopour \& Amini Farsani, 2010; Nikoopour, Amini Farsani, \& Kashefi Neishabori, 2011; Nikoopour, Amini Farsani, \& Nasiri, 2011; Nikoopour, Salimian, Salimian, \& Amini Farsani, 2012; Nikoopour \& Hajian, 2015; Nikoopour, Kargar Moakher, \& Esfandiari, 2017a, 2017b; Oxford et al., 2014; Riazi \& Rahimi., 2005). Due to the fuzziness of learning strategy definition, self-regulation has been used as a replacement which, in turn, is rooted in 
educational psychology (Dorneyi, 2005, cited in Dornyei \& Ryan, 2015). Self-regulation refers to the ability of monitoring and managing one's energy states, emotions, thoughts, and behaviors in ways that are acceptable and producing positive results such as well-being, loving relationships, and learning (Schraw, Crippen \& Hartley, 2006). In fact, it consists of three elements: cognition, metacognition, and motivation. The cognition element includes the skills and habits required for encoding, memorizing, and recalling information as well as thinking critically. The metacognition element includes the skills that enable learners to understand and monitor their own cognitive processes. The motivation element deals with the beliefs and attitudes that affect the use and development of both the cognitive and metacognitive skills.

In the early grades, teachers play significant roles in regulating learners' goals in the classroom, however, as they advance to higher grades, this support is reduced from teacher's side, and students self-regulate their learning and decide what to do with their homework (Zimmerman, 1998). According to Ramdass and Zimmerman (2011), it is important that teachers, before assigning any homework, consider students' age, grade level, and the subject matter. That is, shorter and easier material is assigned to elementary students and as they move to higher grades, the level of complexity increases. Also, the assigned homework could be negotiated with the students as well as their parents.

According to De Boer et al. (2013), strategy instruction should teach learners how, when, and why to use selfregulated methods (general metacognitive knowledge). Besides, the instruction should include metacognitive strategy 'planning and prediction' and the motivational strategy 'task value'. In the same way, Effeney, Carroll, and Bahr (2013) investigated nine male students with the age range of 15 to 17 to find their main self-regulated learning strategies and found that habits originated from the family relevant to homework as well as study routines developed the base for SRL effectiveness. Teacher's role as the most important source especially at the early grades is valued and students at the higher levels rely mostly on themselves. Keller-Schneider (2014) investigated self-regulated learning in teacher education and concluded that the intensity of the use of learning opportunity is important in learning settings requiring self-regulation. In situations which require analyzing and evaluation, strategies like elaboration, organization, and selfmotivation are necessary. In addition, Mahmoodi et al. (2014) studied Iranian EFL learners' self-regulated learning, motivation and their language achievement, and concluded that cognitive and metacognitive SRL are favored by Iranian EFL learners. Besides, self-regulation and motivation assist EFL learners to learn better, however, no significant relationship was found between SRL strategies and L2 achievement of the learners.

The present study aimed at exploring the relationship between male and female EFL learners' learning styles and self-regulated learning. More specifically, the following research questions were raised:

1. Is there any relation between beginner EFL learners' learning styles and self-regulated learning?

2. Is there any relation between intermediate EFL learners' learning styles and self-regulated learning?

3. Is there any relation between advanced EFL learners' learning styles and self-regulated learning?

4. Is there any interaction between the gender, level of proficiency, learning styles, and self-regulated Learning?

\section{THE STUDY}

Participants: Multi-stage sampling procedure was used to select the participants. At first, five universities were chosen based on purposive sampling. Then, 200 pupils majoring in TEFL, Literature, and Translation Studies were selected through convenience sampling. All the participants took the proficiency test including vocabulary, reading, and grammar. The participants fell into three groups, i.e., beginner, intermediate, and advanced based on their test scores. Finally, from each group, thirty students were selected randomly. The participants were all informed about the purpose of the study and they were assured that the collected data would be kept confidential and their scores would not affect their academic achievement.

Design: Due to the nature of the study, a correlational research design was used. The relationship between selfregulated learning and the learning styles was computed. The learners' gender and level of proficiency were also taken into consideration.

Instrumentation: In the present study, the Self-Regulation Questionnaire (SRQ) developed by Brown, Miller, and Lawendowski (1999) was administered to the participants. It consisted of 63 items measuring different constructs: receiving, evaluating, triggering, searching, formulating, implementing, and assessing. The reliability of the SRQ was computed through using Cronbach alpha, and the reliability index was 0.84, which was acceptable.

The second research instrument was the Learning Style Survey developed by Cohen, Oxford, and Chi (2001) consisting of 11 major activities representing 12 different aspects of one's learning style. The researcher clarified the terms which were not familiar to the participants. The reliability of the instrument, estimated through using Cronbach alpha, was .79, which was reasonable.

The third instrument was a paper and pencil TOEFL test adopted from sample TOEFL preparation book by Longman Publications (2014). The reliability of the test was calculated through running KR-21 method, and the reliability index was 0.76 accordingly.

Procedure: In order to correlate the participants' self-regulations with their learning styles and also measure their level of proficiency, the following procedure was followed: first, the TOEFL test was administered to learners to measure their proficiency level. Then the participants filled out the Self-Regulation Questionnaire (SRQ) including 63 items on a 5-point Likert scale. Finally, the Learning Style Survey questionnaire was administered which contained 11 
major activities representing 12 different aspects of one's learning styles. The questionnaire was based on a Likert scale with the following scale points: 0) never, 1) rarely, 2) sometimes, 3) often, and 4) always. Finally, the completed questionnaires were collected, coded, and scored. The data on all items of each questionnaire and different components of the questionnaire were computed and converted into interval data.

\section{Data AnAlysis}

The data were displayed based on descriptive and inferential statistics. For the first three questions, Pearson correlation was utilized. However, for the last research question (exploring the interaction between the learners' gender, level of proficiency, self-regulated learning and learning styles), the groups' scores were submitted to Multivariate Analysis of Variances.

As shown in Table 1, the correlation between the beginner EFL language learners' learning styles and self-regulated learning is statistically significant. $(\mathrm{r}=.051, \mathrm{n}=30, \mathrm{p}=0.001<0.05)$. Therefore, it could be argued that based on the first research question, the null hypothesis restated as, "There is no correlation between beginner EFL learners' self regulation and their learning styles" is rejected.

TABLE I

\begin{tabular}{|c|c|c|}
\hline$\overline{\text { DV }}$ & Measure & IV (Learning Styles) \\
\hline \multirow[t]{3}{*}{ Self-regulation } & Pearson Correlation & 0.51 \\
\hline & Sig. (2-tailed) & 0.001 \\
\hline & $\mathrm{N}$ & 30 \\
\hline
\end{tabular}

As shown in Table 2, the correlation between the intermediate EFL language learners' learning styles and selfregulated learning is statistically significant. $(\mathrm{r}=.054, \mathrm{n}=30, \mathrm{p}=0.001<0.05)$. Therefore, it could be argued that based on the first research question, the null hypothesis restated as, "There is no correlation between intermediate EFL learners' self-regulation and their learning styles" is rejected.

TABLE II

\begin{tabular}{|c|c|c|}
\hline DV & Measure & IV (Learning styles) \\
\hline Self-reg & Pearson Correlation & 0.54 \\
\hline & Sig. (2-tailed) & 0.001 \\
\hline & $\mathrm{N}$ & 30 \\
\hline
\end{tabular}

As shown in Table 3, the correlation between the advanced EFL language learners' learning styles and self-regulated learning is statistically significant $(\mathrm{r}=.056, \mathrm{n}=30, \mathrm{p}=0.001<0.05)$. Thus, it could be argued that based on the third research question, the null hypothesis restated as, "There is no correlation between advanced EFL learners' self regulation and their learning styles" is rejected.

TABLE III

CORRELATION B/T ADVANCED EFL LEARNERS LEARNING STYLES \& SELF-REGULATEd LEARNING

\begin{tabular}{lll}
\hline DV & Measure & IV (Learning Styles) \\
\hline Self-reg & Pearson Correlation & 0.56 \\
& Sig. (2-tailed) & 0.001 \\
& N & 30 \\
\hline
\end{tabular}

As shown in Table 4, the interaction between learners' level of proficiency and their learning styles is not statistically significant. $(\mathrm{F}=1, \mathrm{P}=.36>.05)$. The results indicated that the interaction between learners' gender and their learning styles is not statistically significant. $(\mathrm{F}=0.11, \mathrm{P}=.74>.05)$. Besides, the interaction between EFL learners' gender and self-regulation is not statistically significant $(\mathrm{F}=.09, \mathrm{P}=.75>.05)$. Furthermore, the results revealed that the interaction between EFL learners' gender and proficiency regarding self-regulated learning and learning styles is not statistically significant. $(\mathrm{F}=1.85, \mathrm{P}=.17>.05)$. However, as it could be seen, EFL learners' proficiency significantly affects their self-regulated learning $(\mathrm{F}=2.88, \mathrm{P}=.04<.05)$, whereas the learners' level of proficiency does not affect their learning styles. 
TABLE IV

MUlTIVARIATE ANALYSis OF THE LEARNERS' SELF-REGULATED LEARNING AND LEARNING STYLES (TESTS OF BETWEEN-SUBJECTS EFFECTS)

\begin{tabular}{|c|c|c|c|c|c|c|}
\hline Source & Dependent Variable & $\begin{array}{l}\text { Type III } \\
\text { Squares }\end{array}$ & Df & Mean Square & $\mathrm{F}$ & Sig. \\
\hline \multirow[t]{2}{*}{ Corrected Model } & LS total & $3595.16^{\mathrm{a}}$ & 5 & 719.03 & .78 & .562 \\
\hline & Self-reg & $3211.10^{b}$ & 5 & 642.22 & 1.73 & .136 \\
\hline \multirow[t]{2}{*}{ Intercept } & LS total & 1185541.15 & 1 & 1185541.15 & 1296.91 & .000 \\
\hline & Self-reg & 859068.06 & 1 & 859068.06 & 2324.12 & .000 \\
\hline \multirow[t]{2}{*}{ Proficiency } & LS total & 2934.76 & 3 & 978.25 & 1.07 & .367 \\
\hline & Self-reg & 3194.72 & 3 & 1064.98 & 2.88 & .041 \\
\hline \multirow[t]{2}{*}{ Gender } & LS total & 100.92 & 1 & 100.92 & .11 & .741 \\
\hline & Self-reg & 35.81 & 1 & 35.81 & .09 & .756 \\
\hline \multirow[t]{3}{*}{ proficiency $*$ gender } & LS total & 1692.29 & 1 & 1692.29 & 1.85 & .178 \\
\hline & Self-reg & 256.34 & 1 & 256.34 & 69 & .408 \\
\hline & Self-reg & 32042.32 & 83 & & & \\
\hline \multicolumn{7}{|c|}{ a. $\mathrm{R}$ Squared $=.048($ Adjusted R Squared $=-.013)$} \\
\hline \multicolumn{7}{|c|}{ b. R Squared $=.100($ Adjusted R Squared $=.043)$} \\
\hline
\end{tabular}

\section{DISCUSSION AND CONCLUSION}

The results of the research revealed that there is a statistically significant relationship between beginner, intermediate, and advanced EFL learners' learning styles and their self-regulation. Thus, it was found that the higher the learners' scores on language learning styles were, the more self-regulated learners they were. Also, between language learners' learning styles and their gender no significant relationship was detected. That is, male and female learners did not show differences in their language learning styles. However, certain studies indicated that gender matters and males and females have different learning styles (Aries, 1976; Dorval, 1990; Fox, 1990; Greb, 1999; Leet-Pellegrini, 1980; Marcus, 1977; Ong, 1989; Pizzo, 1990; Sadeghi, 2012; Thompson, 1975).

It was also explored that self-regulation and gender have no significant interaction, that is, both male and female language learners are self-regulated in the same way. This finding contradicts with the findings of previous studies (Jordan, 2013; Lee, 2002; Young \& McSporran, 2001; Zimmerman \& Martinez-pons, 1990), arguing that male and female learners show differences in using self- regulation (Bidjerano 2005; Hargittai \& Shafer, 2006; Lee, 2002; Young \& McSporran, 2001; Zimmermann \& Martinez-Pons, 1990). Such a contradiction might be related to the differences in the context of the study as well as the number of the participants in the studies, which need to be investigated by some other researchers.

Language proficiency was another variable which was studied to see whether there was a relationship between learning styles and language proficiency. In addition, the researchers attempted to investigate if language proficiency affects self-regulation. As it was reiterated in the result section, EFL learners' proficiency significantly affected their self-regulation which was in line with a study done by Sahebkheir and Davatgari (2014) as well as Nabavi and Shangarfam (2012), in that the learners who improved their self-regulatory strategies were more proficient.

However, in this study, learners' level of proficiency did not affect their learning styles which was in line with the findings of Yeow, Tan, Loh, and Blitz (2010), who found that there was no relationship between self-rated proficiency in English and learning style preference. Such finding was contrary to the findings of the study done by Mirhassani, Akbari, and Dehghan (2007).

Due to the sample size of the study, the results must be interpreted with great care. Other researchers are recommended to replicate a study using different sample sizes. There might be some differences between the learners' different types of learning styles and different dimensions of self-regulation, which due to the limitations, were not addressed in the present study. Other researchers are recommended to replicate the same study investigating the EFL learners' use of different learning styles and different dimensions of self-regulation.

\section{REFERENCES}

[1] Aries, E. (1976). Interaction Patterns and Themes of Male, Female and Mixed Groups. Small Group Behavior, 7(1), 17-18.

[2] Armstrong, S.J., Peterson, E. R. \& Rayner, S. G. (2012). Understanding and defining cognitive style and learning style: a Delphi study in the context of educational psychology. Educational Studies, 38 (4), 449-455.

[3] Bailey, P., Onwuegbuzie, A.J., \& Daley, C.E. (2000). Using learning style to predict foreign language achievement at the college level. System, 28, 115-133.

[4] Bandura, A. (1991). Social cognitive theory of self-regulation. Organizational Behavior and Human Decision Processes, 50 , 248-287.

[5] Banisaeid, M. (2013). Comparative Effect of Memory and Cognitive Strategies Training on EFL Intermediate Learners' Vocabulary Learning. English Language Teaching, 6(8), 108-118.

[6] Banisaeid, M. \& Huang, J. (2015). Exploring Iranian EFL Learners' Perceptual Learning Styles Preferences, Language Learning Strategy Uses and Self- Regulated Learning Strategies. IJSELL, 3(3), 30-40.

[7] Bidjerano, T. (2005). Gender differences in self-regulated learning. Paper presented at the Annual Meeting of the Northeastern Educational Research Association, October 19-21, Kerhonkson, NY, USA. 
[8] Brown, H. D. (2007). Principles of language learning and teaching (5th ed.). New Jersey: Prentice Hall Regents.

[9] Brown, M., \& Miller, W. R. Lawendowski. (1999). The Self-Regulation Questionnaire (SRQ).

[10] Chamot, A. U. (2004). Issues in language learning strategy research and teaching. Electronic Journal of Foreign Language Teaching, 1(1), 14-26.

[11] Chen, M.L. (2009). Influence of grade level on perceptual learning style preferences and language learning strategies of Taiwanese English as foreign language learners. Learning and Individual Differences, 19(2), 304-308.

[12] Cohen, A. D. (2003). The learner's side of foreign language learning: Where do styles, strategies, and tasks meet? International Review of Applied Linguistics in Language Teaching, 41(1), 279-291.

[13] Cohen, A. D., Oxford, R. L., \& Chi, J. C. (2001). Learning style survey. Retrieved May, 19, 2005.

[14] Curry, L. (1983). An Organization of Learning Styles Theory and Constructs. Paper presented at the Annual Meeting of the American Educational Research Association.

[15] De Boer, H., Donker-Bergstra, A. S., Kostons, D. D. N. M., Korpershoek, H., \& Van der Werf, M. P. (2013). Effective strategies for self-regulated learning: A meta-analysis. GION/RUG.

[16] Derakhshan, A., \& Shakki, F. (2018). An investigation into the relationship between Iranian EFL high-and low-proficient learners and their learning styles. SAGE Open, 8(4), 2158244018809408.

[17] Dörnyei, Z. (2005). The psychology of the language learner: Individual differences in second language acquisition. Lawrence Erlbaum.

[18] Dörnyei, Z. \& Ryan, S. (2015). The Psychology of the Language Learner Revisited. Routledge, New York/London.

[19] Dorval, B. (1990). Conversational Coherence and its Development. Norwood, NJ: Ablex.

[20] Effeney, G., Carroll, A., and Bahr, N. (2013). Self-Regulated Learning: Key Strategies and Their Sources in a Sample of Adolescent Males. Australian Journal of Educational \& Developmental Psychology, 13, 58-74.

[21] El-dib, M. A. B. (2004). Language learning strategies in Kuwait: Links to gender, language level, and culture in a hybrid context. Foreign Language Annals 37(1), 85-95.

[22] Ehrman, M. (1996). Second language learning difficulties: Looking beneath the surface. Thousand Oaks, CA: Sage.

[23] Fox, T. (1990). Gender interest in reading and writing. Norwood, NJ: Ablex.

[24] Gilakjani, A., P. \& Ahmadi, M. R. (2011). A Study of Factors Affecting EFL Learners' English Listening Comprehension and the Strategies for Improvement. Journal of Language Teaching and Research, 2 (5), 977-988.

[25] Greb, F. (1999). Learning Style Preferences of Fifth through Twelfth Grade Students. NJ: Prentice Hall.

[26] Gregersen, T. \& MacIntyre, P.D. (2014). Language learning styles. In Z. Dornyei, \& S. Ryan, The Psychology of the Language Learner Revisited. Routledge. New York/London.

[27] Gregersen, T., \& MacIntyre, P. D. (2014). 6 Language Learning Styles. In Capitalizing on Language Learners' Individuality (pp. 174-210). Multilingual Matters.

[28] Griffiths, C. (2003). Patterns of language learning strategy use. System 31(3), 367-383.

[29] Griffiths, C. (2007). Language learning strategies: students' and teachers' perceptions. ELT Journal, 61 (2), 91-99.

[30] Griffiths, C., \& Oxford, R. L. (2014). The twenty-first century landscape of language learning strategies: Introduction to this special issue. System, 43(1), 1-10.

[31] Hargittai, E. \& Shafer, S. (2006). Differences in actual and perceived online skills: The role of gender. Social Science Quarterly, 87 (2), 432-448.

[32] Jordan, M. (2013). Looking at Gender Differences in Preschoolers' Self-Regulation Through Multiple Lenses (Doctoral dissertation).

[33] Keefe, J. W. (1988). Development of the NASSP learning style profile. In J.W. Keefe (Ed.), Profiling and utilizing learning style (pp. 1-17). Reston, VA: NASSP.

[34] Keller-Schneider, M. (2014). Self-Regulated Learning in Teacher Education-The Significance of Individual Resources and Learning Behavior. Australian Journal of Educational \& Developmental Psychology, 14, 144-158.

[35] Khojasteh, Z., \& Pishkar, K. (2015). The Relationship between Iranian EFL Learners' Sensory Learning Style and Their Autonomy Level. Journal of Applied Linguistics and Language Research, 2(6), 179-189.

[36] Kopp, C.B. (1989). Regulation of distress and negative emotions: A developmental view. Developmental Psychology, 25, 343354.

[37] Lee, I.S. (2002). Gender differences in self-regulated on-line learning strategies within Korea's University context. Educational Technology Research and Development, 50 (1), 101-109.

[38] Leet-Pellegrini, H. (1980) Conversational Dominance as a Function of Gender and Expertise. In H. Giles, W. Robinson \& P. Smith. (ed.). Language: Social Psychological Perspectives. New York: Pergamon.

[39] Mace, F. C., Belfiore, P. J., \& Hutchinson, J. M. (2001). Operant theory and research on self-regulation. In B. J. Zimmerman \& D. H. Schunk, (Eds.). Self-regulated learning and academic achievement theoretical perspectives, (pp.39-66). New Jersey, NJ: Lawrence Erlbaum Associates Publisher.

[40] Magogwe, J. M., \& Rhonda, O. (2007). The relationship between language learning strategies, proficiency, age and selfefficacy beliefs: A study of language learners in Botswana. System, 35 (3), 338-352.

[41] Mahmoodi, M. H., Kalantari, B., \& Ghaslani, R. (2014). Self-Regulated Learning (SRL), Motivation and Language Achievement of Iranian EFL Learners. Procedia - Social and Behavioral Sciences, 98, 1062-1068.

[42] Marcus, L. (1977). A Comparison of selected ninth-grade male and female students' learning styles. New York: Oxford University Press.

[43] Mirhassani, A., Akbari, R., \& Dehghan, M. (2007). The relationship between Iranian EFL learners' goal- orientation and selfregulated learning and their language proficiency. TELL, $1(2), 117-132$.

[44] Nabavi, N. \& Shangarfam, N. (2012). The Relationship between Determinant Factors of Self-Regulation Strategies and Main Language Skills and Overall Proficiency. Social and Behavioral Sciences, 70(1), 137-147. 
[45] Najarkolai, A.R., Beigzadeh, A., Motlagh, M. K. \& Sabzevari, S. (2015). The Relationship between Learning Styles and Baseline Characteristics of Postgraduate Students at Kerman University of Medical Sciences during 2013 - 2014. Thrita, 4(2): e27809.

[46] Najeeb, S.R. (2013). Learner autonomy in language learning. Procedia-Social and Behavioral Sciences, 70; 1238-1242.

[47] Naserieh, F., \& Anani Sarab, M.R. (2013). Perceptual learning style preferences among Iranian graduate students. System, $41(1), 122-133$.

[48] Nikoopour,J. \& Amini Farsani, M. (2010). On the Relationship between Language Learning Strategies and Cognitive Styles among EFL Iranian Language Learners. Proceedings of 2010 CALL Conference, University of Antwerp., 40-43.

[49] Nikoopour, J., Amini Farsani, M., \& Kashefi Neishabouri, J. (2011). Language learning strategy preferences of Iranian EFL students. In International Conference on Social Science and Humanity IPEDR (Vol. 5, pp. 356-360).

[50] Nikoopour, J., Amini Farsani, M. \& Nasiri, M. (2011). On the Relationship between Critical Thinking and Language Learning Strategies among Iranian EFL Learners. Journal of Technology \& Education, 5(3), 195-200.

[51] Nikoopour, J., Salimian, S., Salimian, S., \& Amini Farsani, M. (2012). Motivation and the Choice of Language Learning Strategies. Journal of Language Teaching \& Research, 3 (6), 1277-1283.

[52] Nikoopour, J., \& Hajian, M. (2015). An Exploration on the Relationship among Learners' Autonomy, Language Learning Strategies and Big-Five Personality Traits. IOSR Journal of Humanities and Social Science (IOSR-JHSS), 20 (2), 66-71.

[53] Nikoopour, J., Kargar Moakher, R., \& Esfandiari, N. (2017a). Explicit Instruction of Memory vs Cognitive Strategies and Reading Comprehension: An Empirical Study with IELTS Candidates. Studies in English Language Teaching, 5 (2), 134-148.

[54] Nikoopour, J., Kargar Moakhar, R., \& Esfandiari, N. (2017b). The Impact of Explicit Integrated Strategies Instruction on IELTS Applicants' Listening Comprehension. Journal of Language Teaching and Research, 8 (4), 774-781.

[55] Ong, W. (1989). Fighting for life: contest, sexuality, and consciousness. NY: Cornell University Press.

[56] Oxford, R, Ehrman, M., \& Lavine, R Z. (1991). Style wars: Teacher-student style conflicts in the language classroom. In S. S. Magnan (ed), Challenges in the 1990s for College Foreign Language Programs. Boston, MA: Heinle and Heinle, 1-25.

[57] Oxford, R. L. \& Anderson, N. J. (1995). A cross-cultural view of learning styles. Language Teaching, 28,201-215.

[58] Oxford, R. (2003). Language learning styles and strategies. Berlin: Mouton de Gruyter.

[59] Oxford, R. L., Griffiths, C., Longhini, A., Cohen, A. D., Macaro, E., \& Harris, V. (2014). Experts' personal metaphors and similes about language learning strategies. System, 43, 11-29.

[60] Peacock, M. (2001), Match or mismatch? Learning styles and teaching styles in EFL. International Journal of Applied Linguistics, 11, 1-20.

[61] Pizzo, J. (1990). Responding to students' learning styles. St. John's University. NY.

[62] Pintrich, P. (2004). A conceptual framework for assessing motivation and self-regulated learning in college students. Educational Psychology Review, 16(4), 385-407.

[63] Pritchard, A. (2009). Ways of Learning: Learning theories and learning styles in the classroom (2nd ed.). London and New York, Routledge.

[64] Ramdass D., Zimmerman B. J. (2011). Developing self-regulation skills: the important role of homework. Journal of Advanced Academy, 22, 194-218.

[65] Reid, J. M. (1987). The Learning Style Preferences of ESL Students. TESOL Quarterly, 21, 87-111. http://dx.doi.org/10.2307/3586356

[66] Reid, J. (1995). Learning styles in the ESL/EFL classroom. Boston: Heinle \& Heinle.

[67] Riazi, A., \& Rahimi, M. (2005). Iranian EFL Learners' Pattern of Language Learning Strategy Use. Online Submission, 2 (1), 103-129.

[68] Sadeghi, M. R. (2012). EFL Male and Female Learning Styles and Multiple Intelligences A Case of Iranian EFL University Students. Research in English Language Pedagogy, 1(2), 20-28.

[69] Sahebkheir, F., \& Davatgari Asl, H. (2014). The role of self-regulation strategies on developing Iranian EFL Learner's overall language proficiency. Indian Journal of Fundamental and Applied Life Sciences, 4(S4), 1156-1161.

[70] Schraw, G., Crippen, K. J., \& Hartley, K. (2006). Promoting self-regulation in science education: Metacognition as part of a broader perspective on learning. Research in Science Education, 36 (1-2), 111-139.

[71] Shah, K., Ahmed, J., Shenoy, N., \& Srikant, N. (2013). How different are students and their learning styles? Int J Res Med Sci, l(3), 212-215.

[72] Thompson, B.G. (1975). Sex differences in reading attainment. Educational Researcher, 18, 16-23.

[73] Yeow, T. P., Tan, M. K. M., Loh, L. Ch. \& Blitz, J. (2010). An Investigation into the Learning Styles, English Proficiency and Assessment Performance of Medical Students. IEJSME, 4 (1), 7-13.

[74] Young, S., \& McSporran, M. (2001). Confident men - successful women: Gender differences in online Learning. In C. Montgomerie \& J. Viteli (Eds.), Proceedings of Ed Media 2001 Conference (pp. 2110-2112), Chesapeake, VA: AACE.

[75] Zimmerman, B. J., \& Martinez-Pons, M. (1990). Student differences in self-regulated learning: Relating grade, sex, and giftedness to self-efficacy and strategy use. Journal of Educational Psychology, 82 (1), 51-59.

[76] Zimmerman, B. J. (1998). Developing self-fulfilling cycles of academic regulation: An analysis of exemplary instructional models. In D. H. Schunk \& B. J. Zimmerman (Eds.), Self-regulated learning: From teaching to self-reflective practice (pp. 119). New York: Guilford Press.

[77] Zimmerman, B. J. (2001). Theories of self-regulated learning and academic achievement: An overview and analysis. In B. J. Zimmerman \& D. H. Schunk (Eds.), Self-regulated learning and academic achievement: Theoretical perspectives (2nd ed., pp. 1-37). Mahwah, NJ: Erlbaum. 


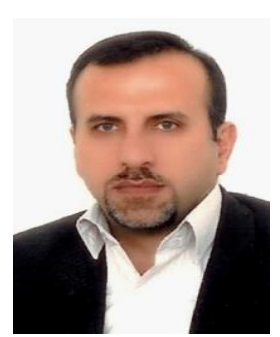

Jahanbakhsh Nikoopour is an assistant professor in Applied Linguistics at Islamic Azad University, Northern Tehran Branch. He was born in Tehran in 1966. He finished his BA studies in TESOL at University for Teacher Education in Tehran in 1990, then accomplished his MA studies at Tarbiat Modarres University in Tehran in 1994. He got his Ph.D. from Islamic Azad University, Science and Research Campus, Tehran, Iran in 2005. His dissertation was "The Wash back Effect of the University Entrance Examinations on EFL Education in Iran."

Dr. Nikoopour is a faculty member in TEFL Department at Islamic Azad University, North Tehran Branch. He has published several papers in domestic and international journals so far. He is also a member of the Editorial Board for some national and international journals related to TESOL. His research interests include language assessment, teacher education, language learning strategies, and learner variables. j_nikoopour@iau-tnb.ac.ir

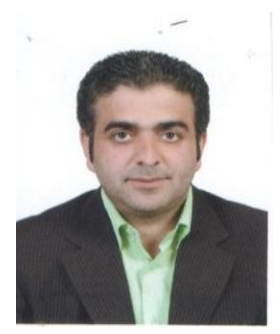

Mohammad Shaker Khoshroudi is a PhD candidate at ELT Department, Faculty of Foreign Languages, Islamic Azad University, North Tehran Branch, Iran. He has taught different courses at Islamic Azad University. Also, he has been teaching English at different language institutes and organizations since 2000. His main research interests include teacher education, critical pedagogy, EFL/ESL, and language assessment. mohammadshaaker1358@gmail.com 